proposal. No special gene therapy study section should be instituted. "It was appropriate to fund [gene therapy] clinical protocols through RFAs, but the panel felt that no more RFAs are needed," says Motulsky,

But what about gene therapy research that is not funded through the NIH extramural program, and thus not subject to NIH-based peer review? Several members of the Director's Advisory Committee expressed concerns that non$\mathrm{NIH}$-funded research is being conducted without the benefit of scientific peer review and suggested that perhaps the role of the RAC should be expanded to judge clinical protocols for scientific merit. The RAC has traditionally evaluated the safety of any recombinant DNA protocols funded by NIH or conducted within NIHfunded institutions. Varmus says NIH and thus the RAC - has no jurisdiction over research conducted without NIH funds or in institutes not receiving NIH funding. "The role of NIH is to fund scientifically worthy research," said Varmus. "It is not a regulatory agency."

However, during the discussion of the report of a second panel commissioned by Varmus to review the role of the RAC (which also reported to Varmus during the advisory committee meeting), some researchers suggested that the RAC should evaluate protocols for quality as well as safety. Francis Collins, director of the National Center for Human Genome Research, suggested that RAC could play a role in evaluating the scientific merit of gene therapy protocols. "I have trouble seeing how the RAC can decide the safety of a protocol without considering the quality of the science," said Collins. "The RAC could take on that role. It would be a more useful model than what has happened in the past." Other researchers contend that RAC is not the appropriate forum for reviewing quality, because all RAC discussions are conducted in public.

Throughout much of the discussion of the role of the RAC and of the quality of science in gene therapy protocols during both committee reports was the undercurrent - tinged with shades of envy that research funded by industry may be evading scientific scrutiny. But Barrie Carter of Targeted Genetics in Seattle, who testified at one of the Gene Therapy Panel meetings, resents the implication that industry is conducting substandard research. "Most companies have a different perspective than those in government and academics," says Carter. "We have to deliver a high-quality product. We can't afford to be channeling money into research that has little scientific merit."

Carter says the state of gene therapy is no different than any other experimental protocol in its early stages. And often the success of a particular therapy cannot be predicted from in vitro or animal models. For example, says Carter, during the early stages of the war on cancer, promising new chemotherapeutics were tested on hundreds of patients, often with great expectations and a similar level of hype. "Lots of patients were treated, but we can't say that many were cured in the early clinical trials," he says. "I don't see why this is any different."

Of great concern to the panel and to members of the Director's Advisory Committee is the overemphasis of gene therapy by researchers in academics, government, and industry, and by the scientific and popular media. "Expectations of current gene therapy protocols have been oversold. ... Such misrepresentation threatens confidence in the field and will inevitably lead to disappointment in both medical and lay communities," wrote the panel in their report.

The hyping of gene therapy is already causing some patients to forgo conventional therapies, said Motulsky, a view echoed by advisory committee member David Valle of Johns Hopkins University in Baltimore. Valle studies a rare metabolic disorder, ornithine aminotransferase deficiency, which can lead to retinal degeneration from an accumulation of ornithine. So far, the only promising treatment for the disorder is adherence to a strict low-arginine diet. "Just last week I had a patient tell me he was abandoning the diet, thinking gene therapy was just around the corner," said Valle.

Perhaps what the panel members fear most from the overzealous reporting of gene therapy's success when no such success yet exists is the undercutting of public support for the otherwise highly promising research. Varmus and the panel members voiced fears that in the current atmosphere of budget cuts, such high expectations will ultimately result in less funding for the research. "I think the therapy will ultimately be forthcoming," says Varmus. "But there has been extrapolation from hope to hype. This will result in disappointment in a therapy I'm deeply hopeful for in the long term."

NANCY TOUCHETTE Washington, $D C$

\section{DID YOU KNOW?}

Mass screen for Chernobyl region

A Japanese charitable foundation has agreed to coordinate and finance a mass screening effort for lung cancer

in people of the Beteka

region of Belarus, an

area in the former

Soviet Union badly

contaminated with

radioactive fallout from

the explosion of the

Chernobyl nuclear

reactor in 1986.

The Chernobyl

Foundation, set up in

1991 by a Buddhist monk in Nagano

Prefecture, northwest of Tokyo, plans to

screen between 1,500 and 2,000 people

from the Beteka region, which is located

$170 \mathrm{~km}$ from Chernobyl. The effort is to be directed by doctors at Shinsyu University in Nagano, and researchers from the Minsk National Cancer Center, Belarus, and will initially screen people over the age of 50 . If successful, the scope of the project will be widened to include a further 50,000 people. RICHARD NATHAN Tokyo

\section{India wages war on polio}

In the biggest anti-polio drive ever undertaken in the country, Indian health officials vaccinated almost all of its 75 million infants and children under the age of three in a single day on 9 December. (A second dose will be given later this month.) The goal of the US\$65-million campaign is to eradicate polio in India before the year 2,000.

Nearly one million volunteers were mobilized for the task. Millions of doses of an oral polio vaccine were delivered to some 500,000 vaccination booths nationwide set up at airports, seaports, railway stations and bus stops. The World Health Organization (WHO) helped in procuring the vaccine, and financial support came from Britain's Overseas Development Agency $(\$ 5.5$ million), Rotary International ( $\$ 5$ million) and the US Agency for International Development ( $\$ 1.25$ million), with the remainder coming from the Indian government.

With nearly 100,000 cases a year, India accounts for 60 percent of polio victims worldwide. 'Pulse immunization', where the vaccine is given to everyone simultaneously, is considered by the WHO to be the best way of wiping out the wild-type virus.

K.S. JAYARAMAN New Delhi 